\title{
Maxwell 型セミアクティブダンパの振動制御能力に関する基礎的考察 FUNDAMENTAL STUDY OF STRUCTURAL CONTROL CAPACITY OF MAXWELL TYPE SEMI-ACTIVE DAMPER
}

\author{
栗 野治 彦* \\ Haruhiko KURINO
}

\begin{abstract}
The objective of this paper is to clarify the maximum control capacity of the Maxwell-type semi-active damper to develop an effective system for structural control. We focus on the force-displacement orbit to understand and consider the physical constraint inherently associated with the Maxwell model. The key conclusions are as follows: 1) A semi-actively controlled damper can realize twice as much damping augmentation as a passive damper. 2) A simple on/off control scheme is the best strategy for energy dissipation or displacement reduction. 3) There is an optimum control parameter that minimizes the acceleration or the story shear force, and this parameter can be directly obtained in accordance with the system stiffness condition.
\end{abstract}

Keywords : semi-active control, Maxwell model, equivalent linearization, velocity feedback, energy dissipation capacity セミアクティブ制御、マックスウェルモテル、等価線形化、速度フィードバック、エネルギ吸収能力

\section{1.はじめに}

近年、構造物の振動制御を目的とした様々な種類のセミアクティ ブダンパの開発が進められている ${ }^{1) \sim 9 \% 。 セ ミ ア ク テ ィ フ ゙ タ ゙ ン ハ ゚ は 、 ~}$ 僅かな供給エネルギにより装置の受動的な抵抗力を可変に制御する ものであり、パッシブ型と同じ原理に基づく大きな抵抗力を利用で きるため、地震時にも有効な制御装置として期待されている。また、 原理上エネルギを発生しないため建物を加振することもなく、アク ティブ型に比較すればメンテナンスも格段に容易であるという特徵 もある。このようなセミアクティブダンパの代表例として可変才イ ルダンパ 4) 9) が挙げられる。これはオイルダンパに流量制御弁を組 込み、外部から減衰係数を制御できる仕組みとしたものであり、減 衰係数を 2 段階、多段階、あるいは連続的に切り替えられる装置が 既に開発され、実建物 7),8) あるいは橋梁 9)などに適用され始めている。 ところでこうしたオイルダンパでは内封油の圧縮剛性が無視できな いため、力学特性がいわゆる Maxwell モデルで表されることが特徵 であるが、ブレース等の反カ要素を介して建物層間に設置される場 合には、反力要素や設置付帯柱の軸変形等ダンパ周辺構造の変形に よる更なる剛性低下が避けられず、ごく小規模な建物を除けば、装 置部の剛性が建物フレーム剛性に対して相対的に小さな值に限定さ れることが問題となる。したがって、セミアクティブダンパを用い た有効な制震システムを構築するためには、Maxwell モデルに由来す る物理的な制約条件を考慮することが不可欠である。

セミアクティブダンパの制御手法に関する研究はこれまでにも数
多く行われており、LQR (Linear Quadratic Regulator : 最適レギュレ 一夕）あるいはその拡張型を含む現代制御理論の適用は代表的な手

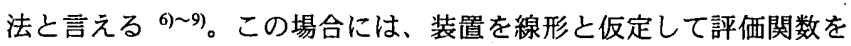
最小にする制御力目標值を算定し、得られた目標値をセミアクティ ブダンパの減衰力で近似させる手法が一般的に用いられる。しかし ながら、この方法では Maxwell モテルの物理的制約（非線形性）が 最適化の過程で考慮されないため評価関数の意味が曖昧となり、設 計が試行錯誤的にならざるを得ないという問題がある。また、LQR 以外にも様々な手法が検討されているが 10) 15)、それぞれが個別の検 討に留まっており、Maxwell 型セミアクティブダンパの振動制御効果 を統一的に定量評価した検討は十分でないのが現状である。

本論文は、セミアクティブダンパの能力を最大限に活かした合理 的な制震システムを構築する上で最も必要な基整的知見でありなが ら、これまで明確でなかった「剛性条件が与えられた Maxwell 型セ ミアクティブダンパの減衰係数を制御することにより物理的に何が 可能か」という問題について考察したものである。制御能力の物理 的な限界が明らかになれば、その最大能力を活かすための制御則あ るいは装置はどうあるべきかを知ることができる。2 章及び 3 章に おいて対象モテルと仮定条件、及びパッシブ型の基本特性について 確認した後、4 章において減衰可変型 Maxwell モテルの物理的拘束 の意味を、荷重変形軌跡の制約という形で明確にする。 5 章では速 度フィードバック制御を適用した 1 質点振動系の制御時特性につい て詳細に検討する。ここでは 4 章の結果を利用して荷重変形関係に 
着目することにより、ダンパ部の動的な特性（見かけの剛性や減衰） やエネルギ吸収能力についてパッシブ型との比較を含め定量的に明 らかにし、かつ従来数值解析的にしか検討されていなかった目標応 答量（加速度あるいは変位）に応じたフィードバックゲインの簡便 な算定法を示し、地震応答解析により検証する。速度フィードバッ ク制御を取り上げた理由は、物理的な意味が明快でエネルギ吸収能 力と直結した考察が可能であり LQR とも密接に関係した制御則であ ること、及び Maxwell モデルの制御能力が速度フィードバック制御 のみで包括的に考察可能であるためである。6 章において、他の状 態量をフィードバックした場合や LQR の適用性についても考察する。

\section{2. 検討力学モデルと仮定条件}

装置が組込まれた建物の力学特性を表す最も基本的なモデルであ る 1 質点振動モテルを図 1 に示す。 $M$ 及び $K_{f}$ はそれぞれ建物質量及 び建物フレーム剛性を表し、Maxwell モテルの部分が装置部を表して いる。 $k$ はブレース等の反力要素の変形を全て含んだ剛性、 $C(t)$ は装 置の減衰倸数を表し、この減衰俰数は $C_{\min } \leq C(t) \leq C_{\max }$ の範囲で連続的 に可変制御できるものとする。なお本論文では $C(t)$ の制御に要する時 間遅れは無視する。また、 $y$ は地動変位、 $x$ は相対変位を表し、 $x_{c}$ は ダッシュポット部の変位（ストローク）を表す。

本モテルでは建物フレーム剛性と装置部剛性の比が重要な意味を 持つため,この比を表すパラメータを導入する。

$$
\alpha=\frac{k}{K_{f}}
$$

$k$ は装置設置構面の配置条件など建築計画により制限される部分が 多く、実現できる値には限りがある。本論文では、考察対象とする 剛性比 $\alpha$ の範囲として、0〜1 程度を考える。なお、 $k 、 K_{f}$ とも弾性と 仮定し、装置荷重制限（いわゆるリリーフ機構）については原則考 慮せず、あくまでばね剛性による拘束条件に焦点を絞ることとする。

\section{3. パッシブダンパの基本特性}

セミアクティブダンパの振動制御能力を議論する前に、最も重要 な比較対象であるパッシブダンパ（ $C=$ 一定）の基本的な特性につい て簡単に示す。円振動数 $p$ の調和変形外力 $x=e^{i p t}$ を考えると、これに 対する Maxwell モデルの複素剛性 $k$ はは次式で表される。

$$
k^{*}=\frac{k C p i}{k+C p i}
$$

1 サイクルにおけるエネルギ吸収量 $\Delta W$ は（2）式の虚部と変位振幅 $\delta$ を用いて $\Delta W=\pi \mathrm{Im}\left[k^{*}\right] \delta^{2}$ と表され、 $C=k / p$ の時に次の最大值をとる。

$$
\Delta W=\frac{\pi}{2} k \delta^{2}
$$

（3）式がパッシブダンパのエネルギ吸収能力の限界を示している。

次に振動系に対する付加減衰能力について調べる。Maxwell モテル が設置された系全体の減衰定数は、 $h=\operatorname{Im}\left[K_{f}+k^{*}\right] /\left(2 \mathrm{Re}\left[K_{f}+k^{*}\right]\right)$ と表され る。ここで振動数 $p$ も変数であるが、共振振動数において $h$ を最大 にする最適減衰係数 $C_{\text {opt }}$ は次の連立式により求められる。

$$
\frac{\partial h}{\partial C}=0 \quad p^{2}=\frac{\operatorname{Re}\left[K_{f}+k^{*}\right]}{M}
$$

（4）式の解を以下に示す。

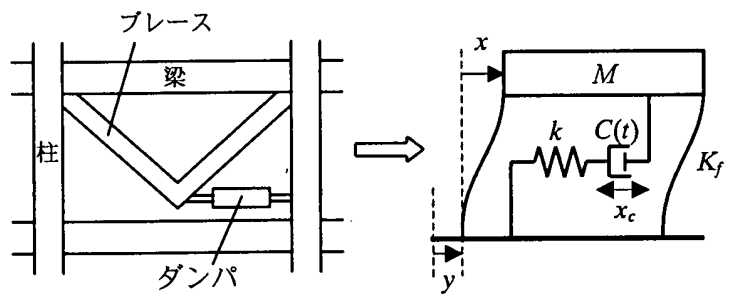

図 1 ダンパ設置建物の簡略力学モテル

$$
\begin{aligned}
& p=\omega \sqrt{\frac{2(1+\alpha)}{2+\alpha}}=\omega_{e} \text { (共振振動数) } \\
& C_{o p t}=\frac{k}{p \sqrt{1+\alpha}}=\frac{k}{\omega} \sqrt{\frac{2+\alpha}{2(1+\alpha)^{2}}}
\end{aligned}
$$

ここで、 $\alpha$ は（1）式で定義された剛性比を表し、 $\omega$ はフレームのみ の建物固有振動数である。

$$
\omega=\sqrt{K_{f} / M}
$$

（6）式の $C_{o p r}$ により実現される最大減衰定数は次式で表される。

$$
h=\frac{\alpha}{4 \sqrt{1+\alpha}}
$$

（3）式及び（8）式より明らかなように、Maxwell 型パッシブダンパ のエネルギ吸収能力あるいは減衰付加能力は、装置部剛性により限 界付けられることが分かる（図6）。

\section{4. 減衰可变型 Maxwell モテルのカ学特性}

セミアクティブダンパの動挙動は次の釣合式により表される。

$$
\frac{\dot{F}}{k}+\frac{F}{C(t)}=\dot{x}
$$

ここで、 $F$ はダンパ荷重であり、 $C(t)$ は時々刻々制御可能な減衰係数 を表している。ここで基本的な問題は、減衰係数を制御することで、 ダンパ発生力がどのように変化するかを明らかにすることである。

時刻 $t$ における装置荷重 $F_{t}$ を初期值とすると、微小時間 $\Delta t$ 経過し た時刻 $t+\Delta t$ における（9）式の一般解は次式で表される。

$$
F_{t+\Delta t}=\exp \left(-\int_{0}^{\Delta t} \frac{k}{C(t+\eta)} d \eta\right)\left\{F_{t}+k \int_{0}^{\Delta t} \dot{x}(t+\eta) \exp \left(\int_{0}^{\eta} \frac{k}{C(t+\tau)} d \tau\right) d \eta\right\}
$$

ここで、 $\eta$ は時刻 $t$ からの経過時間を表すパラメータ $(0 \leq \eta \leq \Delta t)$ で ある。今、微小時間 $\Delta t$ の間に減衰係数が $C_{t} \rightarrow C_{t+\Delta t}$ に直線的に変化す るものと仮定する。すなわち、

$$
C(t+\eta)=C_{1}(1+\gamma \eta / \Delta t)
$$

ここで、 $\gamma$ は減衰係数の変化率を表すパラメータ: $\gamma=\left(C_{t+\Delta r}-C_{t}\right) / C_{t}$ であ る。減衰係数の可変範囲として極限まで $\left(C_{\min } \rightarrow 0 、 C_{\max } \rightarrow \infty\right)$ 考慮 すると、 $\gamma \in[-1, \infty)$ となる。一方、外部変形 $x(t)$ も $\Delta t$ 内で直線変化す ると仮定すると、時刻 $t \sim t+\Delta t$ 間の速度 $\dot{x}(t+\eta)$ は一定值となり、

$$
\dot{x}(t+\eta)=\Delta x / \Delta t
$$

ここで、 $\Delta x=x_{t+\Delta t}-x_{t}(\Delta t$ 間における増分変形）である。（11）式及び （12）式を（10）式に代入すると、時刻 $t+\Delta t$ における荷重は、

$$
F_{t+\Delta}=a F_{t}+b k \Delta x
$$

と表される。ここで、 


$$
\begin{aligned}
& a=\exp \left(-\int_{0}^{\Delta t} \frac{k}{C_{t}(1+\gamma \eta / \Delta t)} d \eta\right)=\exp \left(\left[\ln \left(1+\frac{\gamma \eta}{\Delta t}\right)^{-\frac{k \Delta t}{C_{t} r}}\right]_{0}^{\Delta t}\right)=(1+\gamma)^{-\frac{k \Delta t}{C_{t} r}}(14) \\
& \left.b=\frac{a}{\Delta t} \int_{0}^{\Delta t} \exp \left(\int_{0}^{\eta} \frac{k}{C_{t}(1+\gamma \tau / \Delta t)} d \tau\right) d \eta=\frac{C_{t}(1+\gamma)}{k \Delta t+C_{1} \gamma}\left\{1-(1+\gamma)^{-\left(\frac{k \Delta t}{c_{t} t}\right)}\right)\right\}
\end{aligned}
$$

ちなみに $\gamma=0$ とすると、 $C_{t}$ が一定 (パッシブ)の場合の解を与える。

$$
\begin{aligned}
& a_{(\gamma=0)}=\lim _{\gamma \rightarrow 0}(1+\gamma)^{-\frac{k \Delta t}{C_{t} \gamma}}=e^{-\frac{k \Delta t}{C_{t}}} \\
& b_{(\gamma=0)}=\lim _{\gamma \rightarrow 0} \frac{C_{t}(1+\gamma)}{k \Delta t+C_{t} \gamma}\left\{1-(1+\gamma)^{-\left(\frac{k \Delta t}{c_{t} \gamma}+1\right)}\right\}=\frac{C_{t}}{k \Delta t}\left(1-e^{-\frac{k \Delta t}{C_{t}}}\right)
\end{aligned}
$$

（14）式及び（15）式は、 $\gamma \in[-1, \infty)$ の範囲で $0 \leq a \leq 1 ， 0 \leq b \leq 1$ の 值をとる $\gamma$ に関する単調增加関数である。したがって、減衰係数の可 変範囲として極限 $\left(C_{\text {min }} \rightarrow 0 、 C_{\text {max }} \rightarrow \infty\right)$ まで考慮しても、時刻 $t+\Delta t$ において発生可能な荷重 $F_{t+\Delta t}$ は次の範囲に限定される。

$$
\begin{array}{ll}
F_{t}>0: & 0 \leq F_{t+\Delta t} \leq F_{t}+k \Delta x \\
F_{t}=0: & -k \Delta x \leq F_{t+\Delta t} \leq k \Delta x \\
F_{t}<0: & F_{t}+k \Delta x \leq F_{t+\Delta t} \leq 0
\end{array}
$$

$F_{t}$ と $\Delta x$ が同符号の場合には (18) 式が成り立つことは明らかである。 $F_{t}$ と $\Delta x$ :が異符号の場合にも、変位增分が $|\Delta x| \leq a\left|F_{t}\right|(b k)$ に収まる短い 時間間隔で考えると $F_{t+\Delta t}$ が $F_{t}$ と異符号の範囲に入ることはないため、 やはり（18）式が成り立つことが確認できる。図2は（18）式の制 約を荷重変形平面で(但し $F_{t}>0$ の場合について) 示したものであり、 (a)は現在の荷重 $F_{t}$ と同符号の方向に変位増分 $\Delta x$ が生じる場合、(b) は逆方向の場合である。減衰係数の可変範囲が理想的に広くても、 ダンパの荷重変形軌跡は図 2 中に示した領域内に限定される。（18） 式の物理的意味について考察すると、 $C(t) \rightarrow \infty$ とすると、ダッシュポ ットのストローク移動が拘束されるためダンパ部はばね要素 $k$ と等 しい挙動をし、逆に $C(t) \rightarrow 0$ とすると、これまでばねに蓄えられてい た歪エネルギがダッシュポットにより吸収され、荷重が除荷される と解釈できる。発生力に関する（18）式の制約条件は、Maxwell 型セ ミアウティブダンパの物理的な条件 $(k$ の存在と $C(t) \geq 0$ の条件) によ り定まるものであり、減衰係数を決定する制御則とは無関係である。 したがって（18）式の関係に基づいて様々な制御則を適用した場合 の荷重変形関係を追跡することができるため、制御効果の物理的な 考察が可能となる。

\section{5. セミアクティフ制御時の基本特性}

\section{1 検討制御則（速度フィードバック）}

セミアクティブダンパの減衰係数の制御手法として一般的に用い られている次式を検討対象として取り上げる ${ }^{6) \sim 9 \% 。 ~}$

$$
C(t)= \begin{cases}C_{\max } & :\left(C_{\max }<u(t) / \dot{x}_{c}(t)\right) \\ u(t) / \dot{x}_{c}(t) & :\left(C_{\min } \leq u(t) / \dot{x}_{c}(t) \leq C_{\max }\right) \\ C_{\min } & :\left(C_{\min }>u(t) / \dot{x}_{c}(t)\right)\end{cases}
$$

ここで、 $u(t)$ は各時刻における制御力指令值、 $\dot{x}_{c}(t)$ はダッシュポット 部の速度（図 1 参照）である。（19）式は、ダンパ発生力で制御力指 令值を近似するように隇衰倸数を制御するものである。ここで $u(t)$ の作成方法には何ら制限がなく、各種現代制御理論を含む様々な方 法を適用することができるが、ここでは最も基本的な次の速度フィ ードバックについて検討する。

$$
u(t)=G_{v} \dot{x}
$$

ここで、 $G_{v}$ はフィードバックゲインである。（20）式の物理的な意 味は振動系に対する減衰付加あるいは装置によるエネルギ吸収に他 ならない。ところで（19）式を一見すると、 $u(t)$ と $\dot{x}_{c}(t)$ の向きが等し くかつ $C_{\max }$ が無制限に大きい場合には、どのような大きな $u(t) に も$ 追 従した荷重が発生できるかのように思われるが、（19）式は単に $C(t)$ の制御則を示しているだけであることに注意が必要である。実際の 発生力は、ダッシュポットと直列ばねの相互作用により（18）式の 範囲に限定されることになる。なお、この後の 5.2 5.5 節及び 6 章 における理論的考察に当たっては、減衰係数 $C(t)$ の可変範囲は理想的 に広いもの $\left(C_{\min } \rightarrow 0 、 C_{\max } \rightarrow \infty\right)$ と仮定する。

\section{2 ダンパ部単体の荷重変形関係とエネルギ吸収能力}

定常状態における装置部 (Maxwell モデル) の荷重変形関係につい て調べる。図 3 は層間変形 $x$ と、制御力指令値 $u(t)$ 及び発生荷重 $F$ の 関係を示したものである。A～B'間では $u(t)$ に追随した大きな荷重を 発生しようと $C(t)=C_{\max }$ に制御されるが、装置はばねを剛結した状態 以上の荷重を発生できないため、ばね要素 $k$ と等しい状態に維持さ れたまま $\mathbf{B}$ 点に至る。 $\mathrm{B} \sim \mathrm{C}$ 間では $u(t)$ と等しい $F$ が発生可能とな るため、 $C(t)$ は $C_{\min }$ と $C_{\max }$ の間で時々刻々制御され、 $\mathbf{C} \sim \mathbf{D}$ 間では再 び $C(t)=C_{\max }$ に制御されるというサイクルを繰り返すことで、連続的 な状態量である速度をフィードバックしているにも関わらず装置部 は $\mathbf{A} \rightarrow \mathbf{B} \rightarrow \mathbf{C} \rightarrow \mathbf{D} \rightarrow \mathbf{A}$ の履歴を描く。フィードバックゲイン $G_{v}$ を増 大させるにつれて $u(t)$ と $F$ の乘離は大きくなり、 $G_{v}$ を無限に大きく $\left(G_{v} \rightarrow \infty\right)$ した場合には $C(t)$ は不連続に $C_{\max }$ と $C_{\min }$ の 2 段階に切り 替えられ、履歷ループは $\mathbf{A} \rightarrow \mathbf{B} \rightarrow \mathbf{C} \rightarrow \mathbf{D} \rightarrow \mathbf{A}$ の菱形になる。この菱形 のループこそ Maxwell モデルの構造的な制約条件（18）式のもとで 最大の履歴面積（エネルギ吸収量）を実現するループであり、本論 文ではこれを限界履歴ループと呼ぶこととする。また（20）式を見 ると、フィードバックゲイン $G_{v}$ は制御により元の系に導入しようと 意図された仮想ダッシュポットの减衰倸数を表しているが、実際に

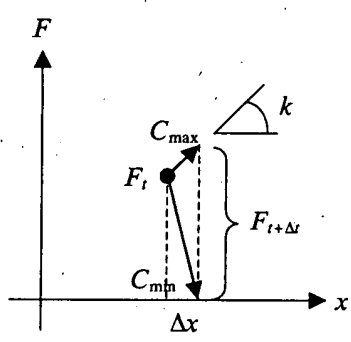

(a) $F_{t} \Delta x>0$

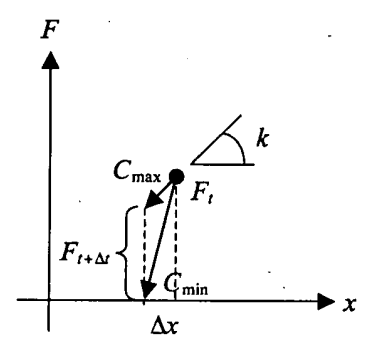

(b) $F_{t} \Delta x<0$

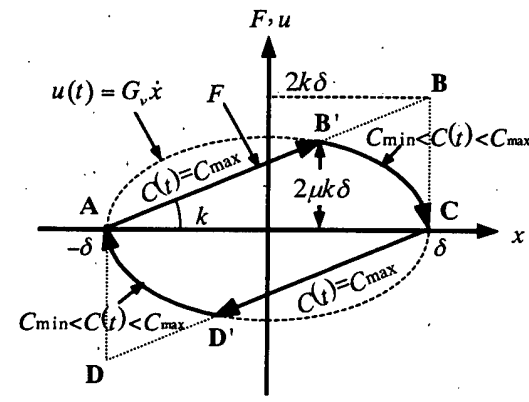

図 3 速度フィードバック時の Maxwell モデル部荷重変形関係

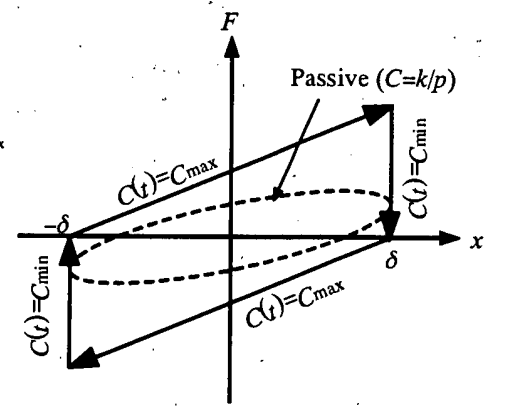

図 4 限界履歴ループと最適 パッシブループの比較

図 2 Maxwell ダンパの荷重制御能力（荷重変形関係表示） 
は限界蕧歴ループの領域内で履歴形状を変化させる間接的な役割を 果たすパラメータであることが分かる。

図 4 は、限界履歴ループと最適設定時のパッシブ（C=k/p）の履歴 ループを比較したものである。限界履歴ループの吸収エネルギ量は、

$$
\Delta W=4 k \delta^{2}
$$

と表されるため、（21）式を（3）式と比較することによりセミアク ティブダンパは理論上パッシブの $8 / \pi(\fallingdotseq 2.5)$ 倍のエネルギ吸収が可 能であることが分かる。

\section{3 等価線形化特性}

図 3 に示した制御時の履歴形状は、装置の発生荷重に制限がなく 振動数が一定であれば振幅に依らず常に相似形となる。そこでこの 特性に着目し、等価線形化手法を利用して制御効果の定量評価を試 みる。応答変位及び速度を円振動数 $p$ の正弦波と仮定して Caughey の等価線形化手法 ${ }^{17}$ ) を用いると、制御時の Maxwell モテル部の等価 㓮性及び等価减衰係数は次式で表される ${ }^{18)}$ 。

$$
\begin{aligned}
& k_{e}=\frac{1}{\pi}(\theta-2 \sqrt{\mu(1-\mu)}) k=S(\mu) \cdot k \\
& C_{e}=\frac{1}{\pi}\left\{\sqrt{\frac{\mu}{1-\mu}}(\pi-\theta)+2 \mu\right\} \frac{k}{p}=V(\mu) \cdot \frac{k}{p} \\
& \text { ここで、 } \theta=\cos ^{-1}(1-2 \mu)
\end{aligned}
$$

上式における $\mu$ は、発生力 $F$ の最大值 $F_{\max }$ （図 3 における $\mathbf{B}^{\text {点の荷 }}$ 重）と限界履歴ループの交点高さを表す形状パラメータであり、 $\mu$ とフィードバックゲイン $G_{v}$ 及び振動数 $p$ の関係は次式で表される。

$$
\mu=\frac{\left(G_{v} p\right)^{2}}{k^{2}+\left(G_{v} p\right)^{2}}
$$

$G_{\nu} p \in[0, \infty)$ に対し $\mu \in[0,1]$ であり、 $\mu=1$ の時に限界履歴ループに一 致する。（22）式及び（23）式は $\theta$ を含んでいるため見通しが悪いが、 いずれも $\mu$ に関する単調増加関数であり、次式でも良好に近似できる。

$$
\begin{aligned}
& S(\mu) \approx 1-\sqrt{1-\mu^{1.5}} \\
& V(\mu) \approx(4 / \pi) \mu^{0.625}
\end{aligned}
$$

$\mu$ と $S(\mu)$ 及び $V(\mu)$ の関係を図 5 に示す。同図より、速度をフィード バックしているにも関わらず、 $\mu$ (ゲイン) の增加に伴い装置部の見 かけの剛性がばね剛性 $k$ の值に近づく $(S \rightarrow 1)$ ことが分かる。

次に、1 質点系の振動特性について考察する。フレームの内部隇 衰を無視すると、定常状態における系の等価振動数 $\omega_{e}$ および等価減 衰定数 $h_{c}$ は、等価線形化特性 $S(\mu)$ 及び $V(\mu)$ を用いて次式で表される。

$$
\begin{aligned}
& \omega_{e}=\sqrt{\left(K_{f}+k_{e}\right) / M}=\omega \sqrt{1+\alpha S(\mu)} \\
& h_{e}=\frac{C_{e}}{2 \sqrt{M\left(K_{f}+k_{e}\right)}}=\frac{\alpha V(\mu)}{2\{1+\alpha S(\mu)\}}\left(\frac{\omega_{e}}{p}\right)
\end{aligned}
$$

ここで $\omega$ はフレームのみの固有振動数（7）式である。限界履歷ルー プ $\left(G_{v} \rightarrow \infty\right)$ の場合には常に $\mu=1$ と定まることから、共振振動数 $\omega_{m}$ 及び共振点における等価減衰定数 $h_{m}$ が簡単に次式で表される。

$$
\begin{aligned}
& \omega_{m}=\sqrt{1+\alpha} \omega \\
& h_{m}=2 \alpha /\{\pi(1+\alpha)\}
\end{aligned}
$$

（30）式をパッシプの最大減衰定数（8）式と比較したものを図 6 に 示す。セミアクティブ制御時には同じ剛性条件のパッシブのほほ 2 倍の付加減衰が実現できることが分かる。

$G_{v}$ が有限な場合の共振時 $\left(p=\omega_{e}\right)$ の特性に着目すると、（24）式の 振動数 $p$ が（27）式と等しくなる条件から、フィードバックゲイン $G_{v}$ と共振点における形状パラメータ $\mu$ の関係が次の様に表される。

$$
G_{v}=\frac{k}{\omega} \sqrt{\frac{\mu}{(1+\alpha S)(1-\mu)}}
$$

ところで $G_{v}$ は減衰係数と等しい次元を有しているため、次の様に無 次元化する。無次元化フィードバックゲイン $G_{h}$ は、制御により元 (フ レームのみ) の系に付与しょうと意図された減衰定数に等しい。

$$
G_{h}=\frac{\omega}{2 K_{f}} G_{v}=\frac{\alpha}{2} \sqrt{\frac{\mu}{(1+\alpha S)(1-\mu)}}
$$

$G_{h}$ を決定すれば（32）式を満足する $\mu$ が一意に定まり、（27）、（28） 式により共振時の $\omega_{e}$ 及び $h_{e}$ が求められる。但し、実際上は $\mu$ を変化 させて $G_{h} 、 \omega_{e} 、 h_{e}$ の関係を図示する方が容易である。図 7 は、剛性 比 $\alpha=0.5$ の場合における $G_{h}$ と $\omega_{e}$ 及び $h_{e}$ の関係を示したものである。 図中にはアクチュエータ（線形装置）の場合を破線で示してある。 $G_{h}$ が小さい範囲では、 $\omega_{e} \fallingdotseq \omega$ のまま $h_{e}$ が $G_{h}$ に比例して增加するが、 $G_{h}$ が限界履歴ループ時の減衰定数 $h_{m}(\alpha=0.5$ の場合は 0.21$)$ 近傍に 達すると、今度は $h_{e}$ はほほ $h_{m}$ 一定のまま $\omega_{e}$ が增加し始め、 $G_{h}$ を非常 に大きくすると $\omega_{e}$ は $\omega_{m}$ に漸近する。 $G_{h}>1$ に設定することは、系を過 隇衰にする発生力を要求することと等価であるが、実現される $h_{e} に$ は Maxwell モデルの制約により定まる上限があることが分かる。以 上の傾向は剛性比 $\alpha$ が異なる場合も同様であり（図 18）、フィードバ ックゲインを変化させることにより、ほほ $h_{m}$ と等しい减衰定数（パ ッシブの約 2 倍）を実現しながら、見かけの振動数（剛性）を制御 できる可能性があることになる。

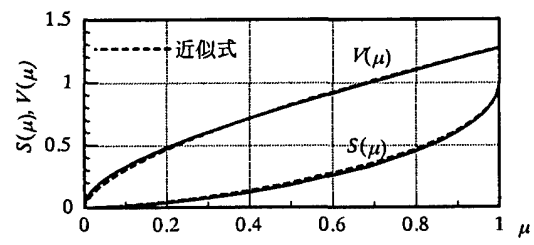

図 5 装置部の等価線形化特性

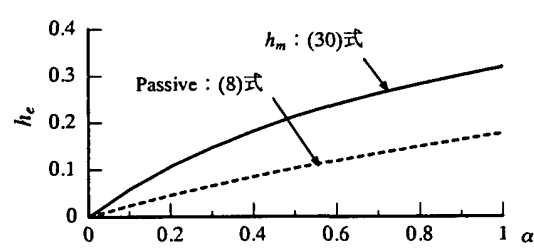

図 6 付加减衰定数比較
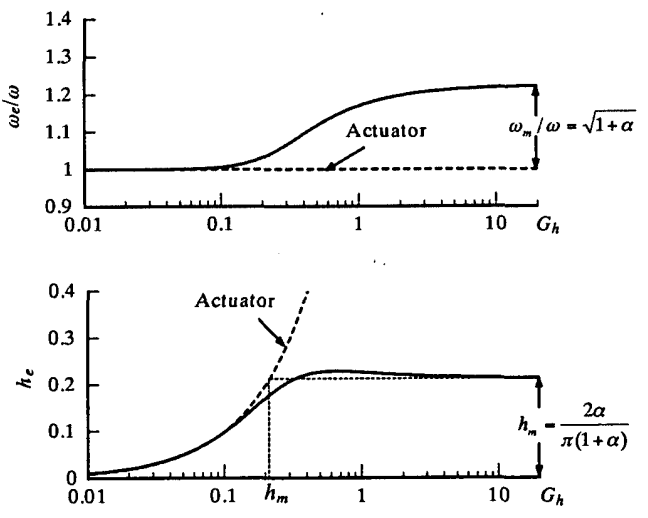

図 7 フィードバックゲインと共振時特性 $(\alpha=0.5)$

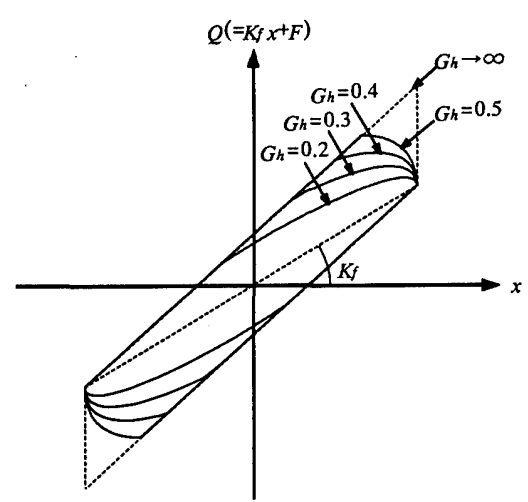

図 8 層全体の荷重変形関係 $(\alpha=0.5)$ 


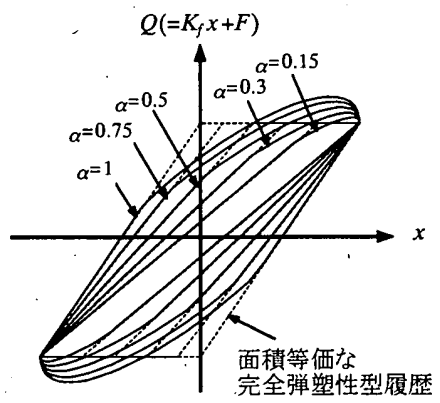

図 9 完全弾塑性型と面積等価な制御時ループ $\left(G_{h}=G_{h 0}\right)$
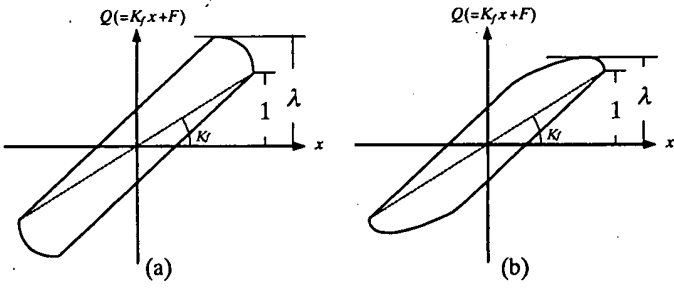

図 10 復元力最大值を表すパラメータ入の定義
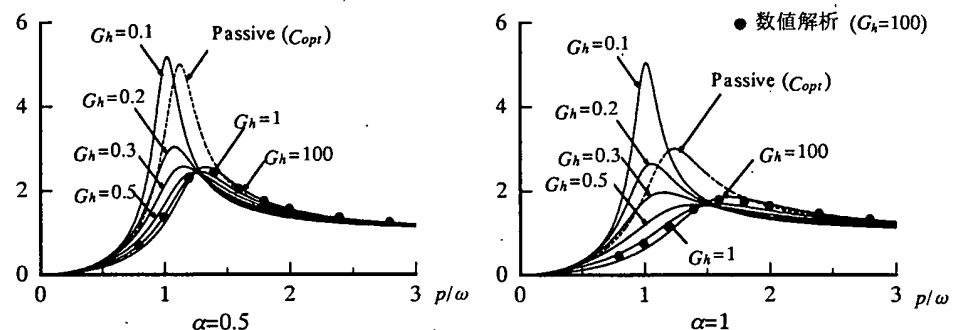

(a) 変位応答倍率
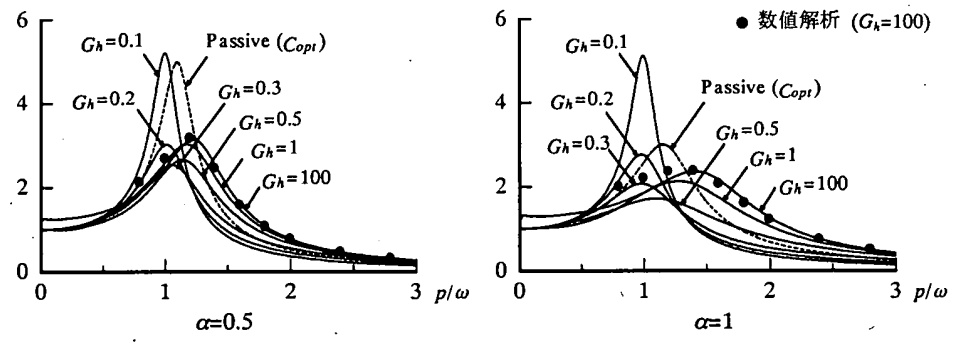

(b) 加速度応答倍率（ピーク值）

図 11 周波数応答特性
図 8 は、特性の分岐点にあたる $G_{h}=h_{m}$ 近傍 $\left(G_{h}=0.2 、 0.3 、 0.4 、 0.5\right)$ の系全体の復元力 $Q\left(=K_{f} x+F\right)$ と変形 $x$ の関係を示したものである。 $G_{h}=h_{m}$ 近傍において、系全体の履歴曲線がいわゆる完全弾塑性型に近 くなっていることが分かる。可変ダンパを設置した系の振動特性が 完全弾塑性型の履歷形状を境に大きく変化することは既に文献[19] で指摘している。完全弾塑性型は系の減衰定数を高く維持しながら 層せん断力を低く保つことができるため、加速度応答に対し最も有 利な形状である（5.5 節）。完全弾塑性型と面積等価になる時の形状 パラメー夕を $\mu_{0}$ と置くと、 $V\left(\mu_{0}\right)=4 /\{\pi(1+\alpha)\}$ が成り立つため、（26） 式より簡単に $\mu_{0} \cong(1+\alpha)^{-1.6}$ と表される。この $\mu_{0}$ を（25）式及び（32） 式に代入すると、 $\mu_{0}$ を実現するフィードバックゲイン $G_{h 0}$ が $\alpha$ のみの 関数として求まるため、これを次の回帰式で表す。

$$
G_{h 0} \approx 0.34 \alpha^{0.45}
$$

様々な剛性比の場合において、ゲインを（33）式で設定した場合の 荷重変形関倸を図 9 に示す。

\section{4 共振曲線}

地震応答について考察する前に、周波数応答特性について調べる。 調和地動 $y=e^{i p r}$ が加わる場合を考えると、変位応答倍率を表す共振曲 線が、等価線形化特性を用いて次式の様に表される。

$$
\left|\frac{x}{y}\right|=\frac{p^{2}}{\sqrt{\left(\omega_{e}^{2}-p^{2}\right)^{2}+\left(2 h_{e} \omega_{e} p\right)^{2}}}=\frac{(p / \omega)^{2}}{\sqrt{\left\{1+\alpha S-(p / \omega)^{2}\right\}^{2}+(\alpha V)^{2}}}
$$

なお、ここでも前節同様フレームの内部減黄は無視するものとする。 フィードバックゲイン $G_{h}$ を決定すれば、 $S$ 及び $V$ は円振動数 $p$ のみ の関数となるため、容易に共振曲線を描くことができる。

次に加速度応答倍率について検討する。絶対加速度（層せん断力） は正弦波とみなせないため、等価線形化特性を用いただけでは正し く評価できない。そこで、履歴ループが振幅によらず一定の形状を 保つことを利用して、絶対加速度の振幅最大值を評価する事とする。 ここで、系全体の復元力最大值 $Q_{\max }$ と、フレーム負担せん断力 $K_{f} \delta$ の関係を表すパラメータ入を導入する（図 10）。

$$
\left(K_{f} x+F\right)_{\max }=\lambda K_{f} \delta
$$

$\lambda$ は幾何学的な関係より、剛性比 $\alpha$ と形状パラメータ $\mu$ により定まり、

$$
\lambda=\left\{\begin{array}{lll}
2(1+\alpha) \mu-1 & : \mu \geq(2+\alpha) /(2+2 \alpha) & \text { [図10(a)] } \\
\sqrt{\mu \alpha^{2} /(1-\mu)+1} & : \mu<(2+\alpha) /(2+2 \alpha) & \text { [図10(b)] }
\end{array}\right.
$$

と表される。（36）式が $\mu$ に応じて場合分けされる理由は、図10(a)の 様にダンパ荷重最大点で首復元力が最大になる場合と、図10(b)の様 な場合があるためである。パラメータスにより、変位応答振幅と加速 度最大値が次の様に関係付けられる。

$$
|\ddot{x}+\ddot{y}|=\frac{\left(K_{f} x+F\right)_{\max }}{M}=\lambda \omega^{2}|x|
$$

（34）式と（37）式より、加速度応答倍率（但しピーク值）を表す 共振曲線が次式の様に得られる。

$$
\left|\frac{\ddot{x}+\ddot{y}}{\ddot{y}}\right|=\frac{\lambda \omega^{2}}{p^{2}}\left|\frac{x}{y}\right|=\frac{\lambda}{\sqrt{\left\{1+\alpha S-(p / \omega)^{2}\right\}^{2}+(\alpha V)^{2}}}
$$

図 11 は、 $\alpha=0.5$ 及び 1 の場合について（34）式及び（38）式を示 したものである。なお、図中には減衰係数 $C$ を（6）式に設定したパ ッシブの場合の共振曲線（次式）も比較のため示してある。

$$
\begin{aligned}
& \left|\frac{x}{y}\right|=\frac{(p / \omega)^{2} \sqrt{1+(C p / k)^{2}}}{\sqrt{\left\{1-(p / \omega)^{2}\right\}^{2}+(C p / k)^{2}\left\{1+\alpha-(p / \omega)^{2}\right\}^{2}}} \\
& \left|\frac{\ddot{x}+\ddot{y}}{\ddot{y}}\right|=\frac{\sqrt{1+(1+\alpha)^{2}(C p / k)^{2}}}{\sqrt{\left\{1-(p / \omega)^{2}\right\}^{2}+(C p / k)^{2}\left\{1+\alpha-(p / \omega)^{2}\right\}^{2}}}
\end{aligned}
$$

図 11(a)より、変位応答倍率はゲイン $G_{h}$ が相対的に小さな時には $G_{h}$ の增大に伴い低減され、更に $G_{h}$ を増大させると今度は応答倍率をほ ほ一定に保ったまま共振点が高振動数側にシフトしていく様子が分 る。一方、図 11(b)の加速度応答倍率は $G_{h}$ の增大に伴って一旦小さく なった後、高振動数側にシフトしながら再び増加する。これは $G_{h}$ と 振動数の増加に伴い、履歴ループの形状パラメータ入が増加するため であり、剛性比 $\alpha$ 大゙きい場合に顕著となる。なお、図 11 中のは、 履歴形状の非線形性が強い $G_{h}=100$ のケースについて行った時刻歴数 値解析の結果を示したものである。解析には 5.6 節で設定したものと 同一のモデル（但し内部減衰無視）を用いた。剛性比 $\alpha$ 大きくなる と低振動数側での合致度がやや悪くなる傾向が認められるが、等価 線形化特性を用いた（34）式及び（38）式により、制御時の周波数 応答特性が概ね良好に評価できることが分かる。 


\section{5 地震応答低減効果の予測評価}

地震応答最大值 $R$ と減衰定数 $h$ の一般的な関係を表す評価式とし ては様々なものが提案されているが、本論文では次式を採用する ${ }^{20) 。 ~}$

$$
R \propto 1 / \sqrt{1+30 h}
$$

ここで減衰定数 $h$ は、建物内部減衰 $h_{0}$ にダンパによる付加減衰 $\Delta h$ を 加えたものである。また、周期と応答の関係について速度スペクト ル一定を仮定すると、減衰定数及び等価振動数の変化を考慮した変 位応答の相対的関係は次式で表される。

$$
R_{D} \propto \frac{1}{\sqrt{1+30\left(h_{0}+\Delta h\right)}}\left(\frac{\omega}{\omega_{e}}\right)
$$

ここで、 $\omega$ はフレームのみの固有振動数を、 $\omega_{e}$ は装置による付加剛 性を考慮した等価振動数を表している。非制御系（装置なし）の応 答変形を $R_{D 0}$ と置くと、制御時の応答变位 $R_{D}$ は次式で表される。

$$
\frac{R_{D}}{R_{D 0}}=\frac{1}{\sqrt{1+n \Delta h}}\left(\frac{\omega}{\omega_{c}}\right)
$$

ここで、 $n=30 /\left(1+30 h_{0}\right)$ である。ここでは $h_{0}=0.02$ を仮定し $n=18.75$ と する。加速度応答は、前節と同様に履歴形状一定の特性を利用して 評価することとし、共振点における $\mu$ に応じて定まる（36）式のパラ メータ入 を用いて、変位応答（43）式を基に次式により評価する。

$$
\frac{R_{A}}{R_{A 0}}=\lambda \frac{R_{D}}{R_{D 0}}
$$

図 12 は、 $\alpha=0.5$ の場合について、横軸に無次元化フィードバック ゲイン $G_{h}$ をとり、縦軸に（43）式及び（44）式で評価した、変位及 び加速度の非制御状態に対する応答比の予測値を示したものである。 変位応答 $R_{D} / R_{D 0}$ はゲインの増加に応じて一様に低下するが、加速度 応答 $R_{A} / R_{A 0}$ はあるゲインで最小になった後再び上昇する。この加速 度を最小にするゲイン $G_{h A}$ は剠性比 $\alpha$ 毎に定まる。図 13 は判性比毎 に調べた $G_{h A}$ と（33）式の $G_{h 0}$ を比較したものである。両者は非常 に良好に対応しており、これより復元力特性が完全弾塑性型と等価 になる場合に加速度応答が最小になることが理解される。したがっ て、重視したい状態量（変位あるいは加速度）に応じて $G_{h 0} \sim \infty の$ 範 囲で $G_{h}$ を設定すればよいことになる。

\section{6 時刻歴解析による検証}

等価線形化特性に基づいた応答低减効果予測の妥当性を検証する ために時刻歷応答解析を行う。解析モデルはフレームのみの固有周 期が 2 秒の 1 質点系 $\left(K_{f}=1.0 \mathrm{kN} / \mathrm{m}\right)$ であり、剛性比 $\alpha$ として 0.15、0.3、 $0.5 、 0.75 、 1$ の 5 ケースを設定し、フレームには内部減衰 $h_{0}=0.02$ を 仮定した。减衰係数 $C(t)$ の可変範囲は十分に広く与えることとし、 $C_{\max }=1 \mathrm{GNsec} / \mathrm{m} 、 C_{\min }=0.1 \mathrm{kNsec} / \mathrm{m}$ と設定した。入力地震動としては、 EL CENTRO(NS)、TAFT(EW)、HACHINOHE（NS)の 3 波を採用し、 最大加速度を全て $100 \mathrm{~cm} / \mathrm{s}^{2}$ に正規化して入力した。フィードバック ゲイン $G_{h}$ の値としては、（33）式により $\alpha$ 毎に算定される $G_{h 0}$ の 0.2、 $0.5 、 1 、 2 、 4 、 10 、 50$ 倍の計 7 ケースを設定した。前節までの予測 評価に従えば、 $G_{h}=\mathrm{G}_{h 0}$ のケースでは層の荷重変形関係は完全弾塑性 型に近く制御されて加速度が最小に、また $G_{h}=50 \mathrm{G}_{h 0}$ のケースではほ ぼ限界履歴ループが実現され変位が最小となるはずである。

図 14 及び図 15 は、 $\alpha=0.5$ のモデルに EL CENTRO(NS)を入力した 時の、層の荷重変形関係、加速度および変位応答波形を示したもの であり、図 14 は $G_{h}=G_{h 0}$ (この場合は 0.25)、図 15 は $G_{h}=50 G_{h 0}$ の結 果である。設定した $G_{h}$ に応じて層の履歴形状がほほ予測した形状に 制御されていることが分かる。ここで、地震店答時の等価振動数 $\omega_{c}$ 及び減衰定数 $h_{e}$ を評価するため、継続時間に渡る制御時変位波形と の 2 乗平均誤差が最小となるような変位応答を生ずる線形 1 質点モ テルを同定した。図 14 及び図 15 の変位波形には同定線形モデルの 波形も破線で重ねて示してあるが両者は良好に対応していることが 分かる。図 16 は、同定された $\omega_{e}$ 及び $h_{e}$ と 5.3 節で評価した等価線形 化特性を比較したものであり、 $h_{e}$ の予測曲線には内部減衰 0.02 が付 加してある。入力波による違いは小さく、 $G_{h}$ に応じて特性が変化し ている様子が分かる。図 17 は、変位及び加速度応答の最大值を予測 曲線上にプロットしたものである。入力波による応答の大小はある ものの、 $G_{h}$ に応じた応答の変化の様子は予測曲線と良好に対応して いることが分かる。図 18 及び図 19 は、剛性比の異なるモデルにお ける応答結果の平均値を、等価線形化特性及び応答予測曲線上にプ ロットしたものである。剛性比 $\alpha$ が 0.3 より大きいケースでは、 $G_{h}$

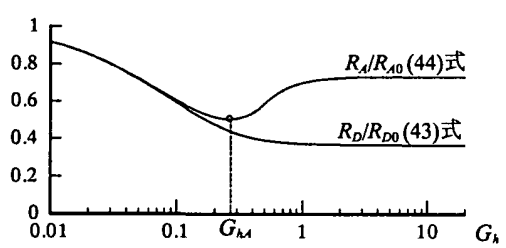

図 $12 G_{h}$ と予測応答值の関係 $(\alpha=0.5)$

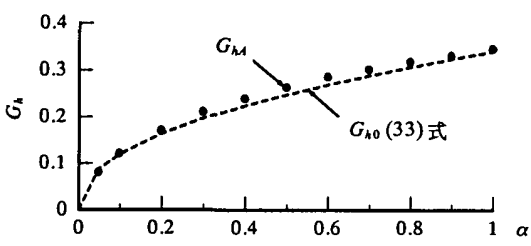

図 $13 G_{h A}$ と(33)式の比較

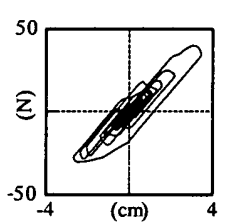

(a)荷重変形

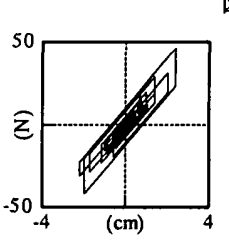

(a)荷重変形

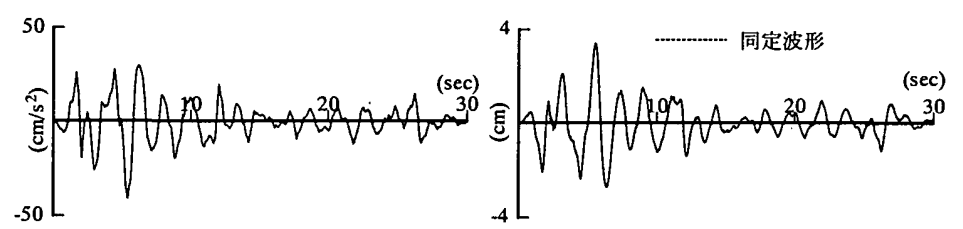

(b) 加速度応答波形

(c) 変位応答波形

図 14 応答解析結果の例 $1 （ \alpha=0.5 、$ EL CENTRO、 $\left.G_{h}=G_{h 0}\right)$

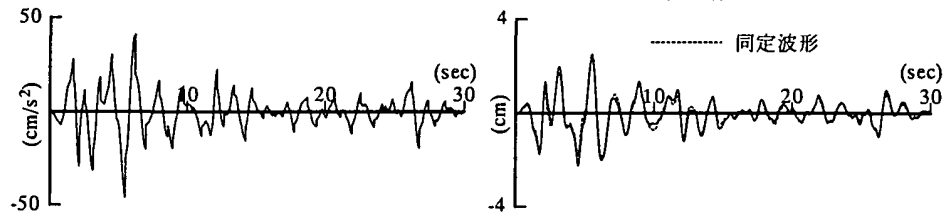

(b) 加速度応答波形

(c) 変位応答波形

図 15 応答解析結果の例 2（ $\alpha=0.5 、$ EL CENTRO、 $\left.G_{h}=50 G_{h 0}\right)$
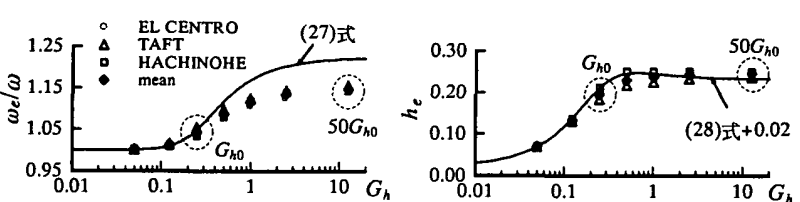

図 16 同定結果と等価線形化特性の比較（ $\alpha=0.5 ）$

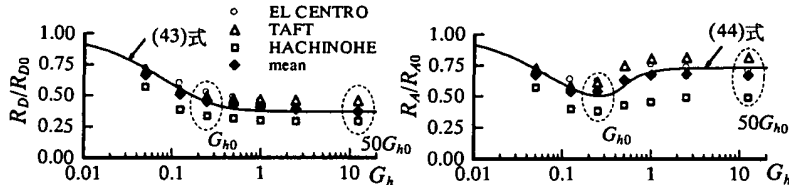

図 17 応答最大值と予測曲線の比較（ $\alpha=0.5 ）$ 

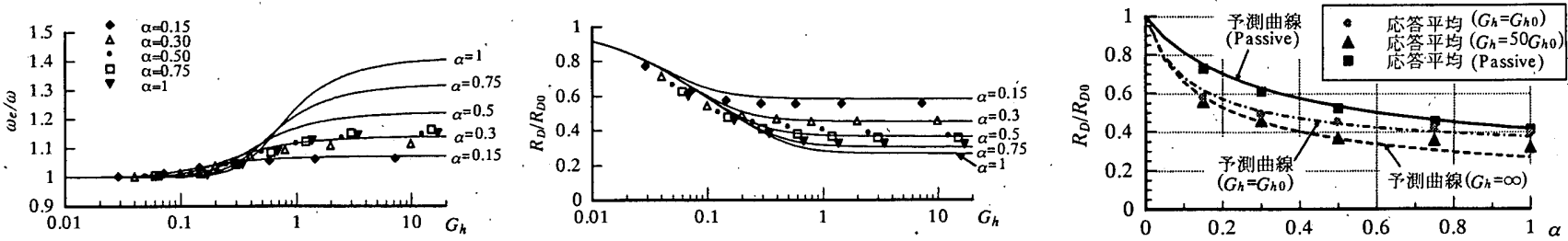

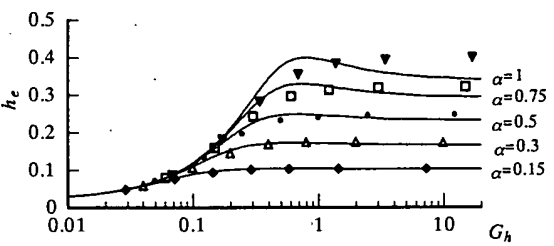

図 18 同定値平均之等価線形化特性の比較

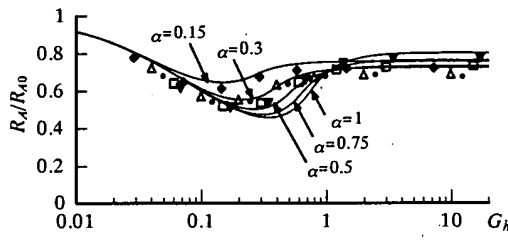

図 19 応答最大値平均と予測曲線の比較

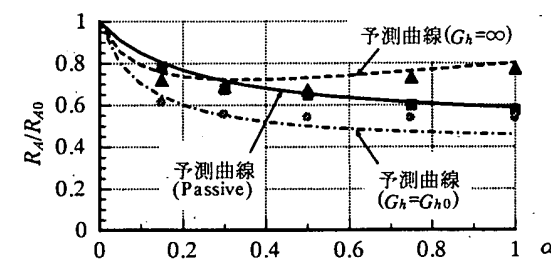

図 20 剛性比と最大応答低減効果の関倸
を增大させても等価線形化手法による予測値ほど振動数（剛性）の 同定結果は高くならず、代りに減衰定数が予測值よりやや高めとな つているが、応答最大值の平均と予測曲線は概ね良好に対応してい ることが確認できる。以上より、変位応答を重視する場合は $G_{h} \rightarrow \infty$ （限界履歴ループ）、加速度応答を重視する場合は $G_{h}=G_{h 0}$ （完全弾塑 性型）に設定するのが妥当であると結論できる。

図 20 は、前述の代表的な 2 つの制御ケースにおける応答低減率と 剛性比の関係を整理して示したものである。図中には、减衰倸数 $C$ を（6）式で設定したパッシブの結果も比較のため示してある。パッ シブの予測曲線を評価するに当たり、等価振動数 $\omega_{e}$ 及び減衰定数 $h_{c}$ はそれぞれ（5）式及び（8）式を用いた。なお、パッシブにおける 層復元力最大值を表すパラメータ $\lambda$ は、 $\lambda=\left|K_{f}+k^{*}\right| K_{f}$ で求まり、Cが （6）式で設定されている場合には $\lambda=\sqrt{1+\alpha}$ となる。図 20 より、 $G_{h}$ $\rightarrow \infty$ (限界履歴ループ) に設定した場合には変位が常に最小となり、 $\alpha=0.5$ の場合でパッシブより更に $30 \%$ 程度低減できることが分かる。 加速度応答は剛性比 $\alpha$ が大きくなるとやや悪化するが、剛性比 $\alpha$ が 0.3 程度以下の範囲では、加速度応答をパッシブと同程度に抑えながら 変位を最大限に低減できることが可能となる。一方、 $G_{h}=G_{h 0}$ （完全 弾塑性型) に設定した場合には、常に加速度と変形をパッシブより 低減することができ、これが $C$ を連続可変的に制御する効果と言え る。但し、剛性比 $\alpha$ が大きくなるとパッシブの効果も向上するため、 制御効果の相対的な差は小さくなる。

\section{6. 他のフィードバック制御時特性に関する考察}

4 章で明らかにした Maxwell モデルの荷重変形関係に関する拘束 条件（18）式を考慮すると、速度フィードバック以外の制御時特性 も同様な手法で考察することが可能となる。

\section{1 速度十変位フィードバック制御}

速度のみでなく変位もフィードバックする場合には、制御力指令 值は一般に次式で表される。

$$
u=G_{v} \dot{x}+G_{d} x
$$

変位をフィードバック量として加えると、速度のみの場合と比較し て指令值の位相が遅れるため、装置発生力の履歴ループは図 21 に示 す形になる。Maxwell 型ダンパで実現できる付加剛性には限界履歴ル 一プにより定まる上限があり、しかも履歴面積は図の様に大幅に減 少するため、変位をフィードバックする意味は極めて少ない。

ここで、LQR（最適レギュレータ）の適用性について考察する。
周知の様に、LQR は 2 次形式の評価関数を最小とするような制御力 を状態量フィードバックの形で得る手法であり、1 質点系に適用した 場合、制御力指令值は（45）式と全く同じ形となる。ここで変位及 び速度にそれぞれかかるフィードバックゲインは、評価関数

$$
J=\int_{0}^{\infty}\left(q_{v} \dot{x}^{2}+q_{d} x^{2}+u^{2}\right) d t
$$

における重み係数 $q_{v} 、 q_{d}$ により決定されるが、速度にのみ重みをか けた場合には速度のみがフィードバックされ、変位にも重みをかけ た場合には速度と変位が両方フィードバックされる ${ }^{21) 。 し か し な か ゙ ~}$ らこれまで示した様に、Maxwell 型セミアクティブダンパでは制御力 指令值と実際の発生荷重との間には大きな乘離があり、設定した評 価関数が本来の意味をなさなくなる。そのため LQR を適用するより はむしろ目標特性に応じて直接的にフィードバックゲインを設定す る方が合理的と考えられる。多質点系の場合には、モ一ド分解法を 用いて各次応答に対し目標履歴を実現するための制御力指令值を作 成する方法等が考えられる。

\section{2 絶対速度フィードバック制御 ${ }^{22)}$}

これはスカイフックダンパとも呼ばれる制御方法であり、応答よ り位相の進んでいる地動速度をフィードバック量に加えることで見 かけ上負剛性を有する履歴を付加し、絶対加速度応答の低减を目論 むものである。この場合の制御力指令值は次の形で与えられる。

$$
u=G(\dot{x}+\dot{y})
$$

（47）式の指令值に対する装置部荷重変形関係を図 22 に示す。やは り Maxwell モデルの構造的な制約のため、指令值と大きくかけ離れ た荷重しか発生されず、もちろん負剛性のループは実現できない。 但し絶対速度をフィードバックすると、図11(b)で観測されたような 高振動数側での加速度增加は避けることができる。しかしながら剛 性比 $\alpha$ が小さい場合には相対速度フィードバッグでもこの加速度増 加は小さんため、地震時の制御効果は $G_{h}=G_{h 0}$ とした相対速度フィー ドバック時とほとんど等しいことが予測される。

\section{3 履歴形状制御を目的とした各種フィードバック制御}

文献[19]では、低減したい状態量に応じて層の履歴形状を直接制御 する非線形制御則が提案されている。例えば、層の履歷形状を完全 弾塑性に制御するための制御力指令值は次式で与えられる。

$$
u=-K_{f}\left\{x-\operatorname{sgn}(\dot{x}) \sqrt{x^{2}+\left(\dot{x} / \omega_{e}\right)^{2}}\right\}
$$

装置部荷重変形関係は図 23 の様になり、速度フィードバック時の様 に近似的ではなく、首として完全弾塑性型の履歴が実現される。こ 


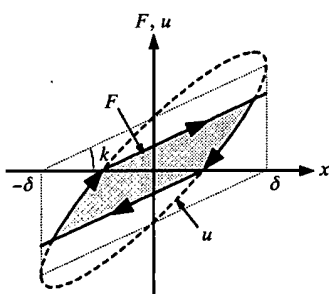

図 21 速度十変位フィード バック時の装置部荷重変形

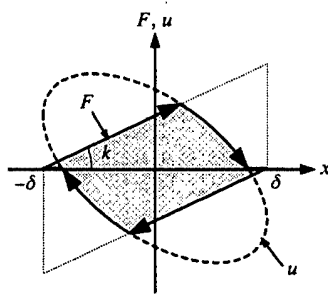

図 22 絶対速度フィード バック時の装置部荷重変形

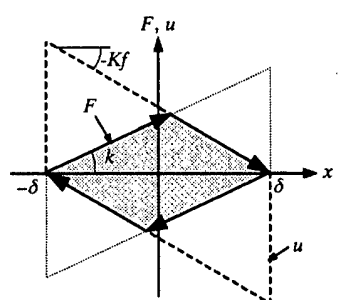

図 23 完全弾塑性型を目的と した非線形フィードバック時

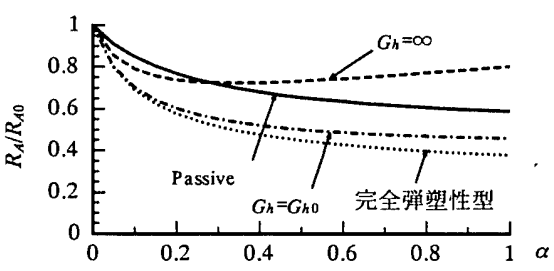

図 24 完全弾塑性型特性を加えた 加速度応答の予測曲線
の時の等価線形化特性はほぼ $\omega_{e}=\omega, h_{e}=h_{m}, \lambda=1$ となるため ${ }^{19)}$ 、この 特性值を用いた加速度応答の予測曲線を図 20 に加えて図 24 に示す。 $G_{h}=G_{h 0}$ とした速度フィードバック時と比較すると、剛性比の大きな 領域では効果の向上が若干見られるものの、㴊性比の小さい範囲で は差は非常に小さいことが分かる。ちなみに、変位応答の予測曲線 は $G_{h}=G_{h 0}$ とした速度フィードバック時と全く重なるため割愛する。 なお、文献[13]でも層の復元力に着目し、ダンパ発生力を含めた層せ ん断力が過去の最大値を超えないようにダンパを制御することを提 案している。この手法では応答が増大する過渡応答時に対して問題 を残しているが、定常状態では完全弾塑性型と一致するためせん断 力（加速度）応答に対しては最適解となる。また、文献[14]では、夕 ンパ部の荷重変形関係を塑性率 2 の完全弾塑性型に制御する手法が 提案されているが、この場合の層の減衰定数は本論文で用いている 記号で表すと $h=\alpha /\{\pi(2+\alpha)\}$ となり、（30）式より小さな值に留まる。

以上の様に、Maxwell 型セミアクティブダンパには限界履歴ループ という不可避な制約が存在するため、減衰係数の制御により実現で きる履歴形状は大幅に制約される。そのため、単純な速度フィード バック制御を対象に導かれた 5 章の結果により、Maxwell 型セミアク ティブダンパの制御能力は包括される。

\section{7. まとめ}

減衰係数可変型 Maxwell モデルの荷重変形関係に着目することに より、セミアクティブダンパの振動制御能力及びその限界について 考察し、以下の知見を得た。

（1）Maxwell 型セミアクティブダンパは吸収可能なエネルギ量に上 限が存在し、これはパッシブの理論值の約 2.5 倍に相当する。 この吸収エネルギ量が最大となる限界履歴ループは変位応答 低減に対する最適解であるだけでなく、剛性比が 0.3 程度以下 の範囲では加速度応答もパッシブより低減できる履歴でもあ る。この履歴ループを実現するためには、ダンパの減衰係数は 最大／最小の 2 段階に切り替えられるだけで良いため、制御則 及びダンパ機構の簡略化が可能である。

（2）减衰倸数を連続的に可変制御することで、パッシブの約 2 倍に 相当する減衰定数を付加しながら、層の等価剛性をある範囲で 制御できる可能性がある。また、層の復元力特性が完全弾塑性 型と等価になるよう制御すれば変位と加速度を常にパッシブ 以下に低減することができる。この履歷は、単純な速度フィー ドバックでも十分近似的に実現でき、そのためのフィードバッ クゲインも剛性比に応じて直接設定することができる。但し、 剛性比が大きくなるとパッシブの効果も向上するため、パッシ ブに対する制御効果の相対的な差は小さくなる。
（1）の結果に着目すると、構造計画上の制約などにより装置部の剛 性比が高くとれない条件下では、ON/OFF 型の簡単な機構の装置で、 パッシブ型を上回る高い制御効果（変位低減に関しては最大の効果） を実現できることになる。次報では、この ON/OFF 型の制御手法を 発展させた簡便で信頼性の高い制御システムの構築について論ずる。

\section{参考文献}

1) Carlson, J.D. and Spencer Jr., B.F. : Magneto-Rheological Fluid Dampers for Semi-Active Seismic Control, Proc., 3rd World Conf. on Motion and Vibration Control, Japan Society of Mechanical Eng., Vol.III, pp.35-40, Chiba, 1996

2) Battaini, M., Casciati, F., Marioni, A., Silvestri, A. and Ubaldini, M. : Semi-active Control by Electro-Inductive Energy Dissipators, Proc., 2nd World Conf. on Struct. Control, Kyoto, Japan, Vol.1, pp.437-444, 1998

3) Hirai, J., Naruse, 'M., Abiru, H. : Structural Control with Variable Friction Damper for Seismic Response, 11WCEE, No.1934, Acapulco, Mexico, 1996

4) Kobori, T., Takahashi, M., Nasu, T., Niwa N., Hiehata, J. and Ogasawara, K. : Seismic Response Controlled Structure with Active Variable Stiffness System, EESD, Vol.22, pp.925-941, 1993

5) Kurino, H., Kobori, T., Takahashi, M., Niwa, N., Kurata, N., Matsunaga, Y., and Mizuno, T. : Development and Modeling of Variable Damping Unit for Active Variable Damping System, 11WCEE, No.01521, Acapulco, Mexico, 1996

6) Symans, M. D. and Constantinou, M. C. : Seismic Testing of a Building Structure with a Semi-Active Fluid Damper Control System, EESD, Vol.26, No.7, pp. 759-777, 1997

7) 倉田成人, 丹羽直幹, 緑川浩史ほか : セミアクティブダンパシステムの奏 建物への適用（その 1 3）, 日本建築学会大会学術講演梗概集, B-2 構造 II, pp.725-730. 1998.9

8) 吉田和夫, 藤尾忠洋: 双線形最適制御理諭とセミアクティブ免震への応用, 日本機会学会論文集 (C 編)，Vol.167(656), pp.992-998, 2001.4

9) Patten, W.N. : Field test of an intelligent stiffener for bridges at the I-35 Walnut Creek Bridge, EESD, Vol.28 No.2, pp.109-126, 1999.2

10) Inaudi, J.A. and Hayen, J.C. : Research on Variable-Structure Systems in the United States, Post-Smirt Conf. Seminar on Seismic Isolation, Passive Energy Dissipation and Control of Vibrations of Structures, Santiago, Chile, 1995

11) Yamada, K. : Control Law for Variable Damping Device defined by a Nonlinear Different Equation, EESD, Vol.28, pp.529-541, 1999

12) Hatada, T., Smith, H.A. : Nonlinear Controller using Variable Damping Device for Tall Buildings, Proc., 2nd World Conf. on Struct. Control, Kyoto, Japan, Vol.1, pp.1539-1548, 1998

13）濱智貴ほか:隊せん断力のセミアクティブ可変減衰制御による建築物の制 震, 日本建築学会大会学術講演梗概集, 21378, 1997.9

14) 西谷章ほか: 可変スリップレベルダンパによるセミアクティブ制御（その 1）制御の概念，日本建築学会大会学術講演梗概集, 21412, 2000.9

15）岩田籁生, 橮智贵, 兽田五月也 : 切替式スライディングモード制御による 最下層にソフトストーリーを有する建築物の制振, 日本建築学会構造系 論文集, 第 516 号, pp.83-90, 1993.2

16）呇野治彦: Maxwell 型セミアクティブダンパによる地震応答低減効果の基 礎的考察, 日本建築学会大会学術講演梗概集, 21401, 1998.9

17) Caughey, T.K. : Sinusoidal Excitation of a System with Bilinear Hysteresis, Journal of Applied Mechanics, ASME, pp.640-643, 1960.12

18) Kurino, H. and Kobori, T. : Self-Regulating Variable Oil Damper for Structural Response Control, Proc., ASME Design Engineering Technical Conferences, Sacramento, VIB3815, 1997

19) Kurino, H. and Kobori, T. : Semi-active Structural Response Control by Optimizing the Force-deformation Loop of Variable Damper, Proc., 2nd World Conf. on Struct. Control, Kyoto, Japan, Vol.1, pp.407-416, 1998

20) 柴田明徳 : 最新耐震構造解析, 森北出版, 1981

21）小䏱鐸二：制震構造一理論と実際一, 鹿島出版会, 1993

22）武田寿一編：構造物の免震・防振・制振，技報堂出版, 1988 